\title{
Modification of ileal proteome in growing pigs by dietary supplementation with inulin or dried chicory root
}

\author{
A. Lepczyński ${ }^{1,3}$, A. Herosimczyk¹, M. Ożgo', M. Barszcz², M. Taciak² and J. Skomiał² \\ ${ }^{1}$ West Pomeranian University of Technology, Department of Physiology, Cytobiology and Proteomics, \\ Klemensa Janickiego 29, 71-270 Szczecin, Poland \\ ${ }^{2}$ The Kielanowski Institute of Animal Physiology and Nutrition, Polish Academy of Sciences, Department of Animal Nutrition, \\ Instytucka 3, 05-110 Jabłonna, Poland
}

KEY WORDS: fructans, intestinal barrier, inulin, mass spectrometry, proteomics, small intestine, metabolism

Received: 9 January 2019

Revised: 13 March 2019

Accepted: 31 May 2019

\begin{abstract}
Recently, numerous plant-based preparations have been used for health promotion or disease prevention in animals. Chicory is one of the plants that contain various nutraceutics, mainly inulin type fructans (ITFs) showing prebiotic character. In pigs, a significant proportion of ITFs is fermented in the distal part of the small intestine to lactate and short-chain fatty acids (SCFAs). Previous studies have shown that SCFAs are involved in structural rearrangement of the intestinal epithelial mucosa and stimulate intestinal barrier assembly. These changes should be accompanied by a modification of enterocyte protein composition and abundance. Thus, we hypothesized that ITFs, due to their direct or indirect effect, can modify ileal proteome. The experiment was performed on 24 castrated male pigs (PIC $\times$ Penarlan P76) assigned to 3 groups $(n=8)$ fed cereal-based diets: control or experimental: supplemented with $4 \%$ of dried chicory root or with $2 \%$ of inulin. Mucosa proteins were separated using two-dimensional electrophoresis, followed by the identification of statistically valid proteins with the aid of Matrix Associated Laser Desorption Ionization - Time of Flight mass spectrometry (MALDI-TOF MS). Experimental diets significantly altered expression of proteins involved in: glycolysis/gluconeogenesis, biosynthesis of amino acids, cytoskeleton rearrangement, protein synthesis and processing, cell proliferation and differentiation, and iron absorption. Changes in the expression of proteins associated with energetic metabolism, cell proliferation and cytoskeleton rearrangement may suggest an impact of dried chicory root on the functional maturation of the ileal mucosa. Additionally, changes in transferrin abundance suggest the significance of chicory root and inulin supplementation for intestinal iron absorption.
\end{abstract}

${ }^{3}$ Corresponding author: e-mail: adam.lepczynski@zut.edu.pl stances of this plant and constitute approximately $63 \%$ of dried chicory root powder (Gałązka, 2002). Purified ITFs are classified as soluble fibre fraction with prebiotic properties, which means that they are carbohydrates resistant to hydrolysis by mammalian enzymes, but are degraded by the symbiotic microbiota and exert positive effects on the host (Gibson et al., 2017). (ITFs) are the main group of health-improving sub-

Recently, numerous plant-based preparations have been used for health promotion or disease prevention in humans and animals. Chicory (Cichorium intybus $\mathrm{L}$.) is one of the attractive plants that contain various nutraceutics. Inulin-type fructans 
In pigs, a significant proportion of ITFs $(20-50 \%)$ is fermented in the distal part of the small intestine (Yasuda et al., 2009). The remaining pool, the size of which differs depending on fructose chain length and dietary level (Barszcz et al., 2018), is fermented by the microbiota in the large intestine to short-chain fatty acids (SCFAs) that may directly or indirectly exert health-improving effects. Previous studies have shown that SCFAs are involved in structural rearrangement of the intestinal epithelial mucosa. Supplementation of a diet with butyrate results in morphological changes in the small intestine epithelium and this effect is positively correlated with the dose (Lu et al., 2008). Additionally, SCFAs stimulate intestinal barrier function by increasing mRNA expression of tight junction-related genes in pigs (Diao et al., 2017). These changes should be accompanied by a modification of enterocyte protein composition and abundance. Since the form of inulin (extract or dried chicory root) may influence pig metabolism (Lepczyński et al., 2016; 2017), we have decided to analyse their influence on ileal mucosa proteome. We hypothesized that ITFs, due to their direct or indirect effect, modify proteome of the distal part of the small intestine.

The present study was aimed to compare the influence of inulin, supplemented as chicory root or water extract of chicory inulin, on the proteome expression pattern of the ileal mucosa in growing pigs.

\section{Material and methods}

\section{Animals and sample collection}

The experiment was performed on 24 castrated male piglets $(\mathrm{PIC} \times$ Penarlan P76). Animals were assigned to 3 groups $(\mathrm{n}=8)$ and fed cereal-based isoenergetic diets: control (C) or experimental supplemented with $4 \%$ of dried chicory root (CR) or with $2 \%$ of inulin extracted from chicory root (IN). In diets for both experimental groups inulin content was similar.

Animal housing and feeding conditions were the same as described by Lepczyński et al. (2017). Detailed composition of the diets is given in Table 1. Briefly, animals were offered experimental diets from the $10^{\text {th }}$ day of life. At weaning, in $28^{\text {th }}$ day of life, male piglets were distributed among group pens $(n=4)$ with free access to feed and water. Feed intake and health status were monitored daily during the whole experimental period. Animals were weighted in two time points: at weaning and at the end of the experiment. At the $50^{\text {th }}$ day of life, at approximately $18 \mathrm{~kg}$ of body weight, animals were euthanized, and
Table 1. Composition of control diet (C) and diets supplemented with $2 \%$ of chicory inulin (IN) or $4 \%$ of dried chicory root (CR)

\begin{tabular}{|c|c|c|c|}
\hline \multirow{2}{*}{ Indices } & \multicolumn{3}{|l|}{ Diet } \\
\hline & $\mathrm{C}$ & IN & $\mathrm{CR}$ \\
\hline \multicolumn{4}{|l|}{ Composition, g/kg } \\
\hline wheat & 468.4 & 468.4 & 458.4 \\
\hline barley & 200.0 & 200.0 & 200.0 \\
\hline maize starch & 30.0 & 10.0 & 0.0 \\
\hline inulin & 0.0 & 20.0 & 0.0 \\
\hline dried chicory root & 0.0 & 0.0 & 40.0 \\
\hline full fat soybean & 59.0 & 59.0 & 59.0 \\
\hline whey & 97.0 & 97.0 & 97.0 \\
\hline fish meal & 40.0 & 40.0 & 40.0 \\
\hline spray-dried plasma & 40.0 & 40.0 & 40.0 \\
\hline soybean oil & 33.9 & 33.9 & 33.9 \\
\hline calcium formate & 3.0 & 3.0 & 3.0 \\
\hline calcium carbonate & 5.0 & 5.0 & 5.0 \\
\hline calcium monophosphate & 6.0 & 6.0 & 6.0 \\
\hline sodium chloride & 0.7 & 0.7 & 0.7 \\
\hline L-lysine HCL (78.5\%) & 6.1 & 6.1 & 6.1 \\
\hline DL-methionine (99\%) & 2.3 & 2.3 & 2.3 \\
\hline L-threonine (98\%) & 2.6 & 2.6 & 2.6 \\
\hline L-tryptophan (98\%) & 0.9 & 0.9 & 0.9 \\
\hline mineral-vitamin mix ${ }^{1}$ & 4.0 & 4.0 & 4.0 \\
\hline aroma & 1.0 & 1.0 & 1.0 \\
\hline \multicolumn{4}{|l|}{ Nutrients, $\%$ dry matter } \\
\hline dry matter, \% & 90.03 & 90.14 & 90.15 \\
\hline crude ash & 4.54 & 4.54 & 4.55 \\
\hline crude protein & 20.05 & 20.04 & 20.05 \\
\hline ether extract & 6.04 & 6.03 & 6.04 \\
\hline crude fibre & 1.52 & 1.51 & 1.53 \\
\hline fructans & 1.00 & 2.21 & 2.74 \\
\hline $\mathrm{EM}^{2}, \mathrm{MJ} / \mathrm{kg}$ & 14.3 & 14.3 & 14.2 \\
\hline
\end{tabular}

${ }^{1}$ supplied per kg of diet: IU: vit. A 2400, vit. $D_{3} 240$; mg: vit. E 12, nicotinic acid 6.4, pantothenic acid 3.2, choline chloride 48, $\mathrm{Mg} 3.2$, Fe 24, Zn 22.4, Mn 9.6, Cu 25.6, I 0.16; $\mu$ g: vit. $\mathrm{K}_{3} 480$, vit. $\mathrm{B}_{1} 480$, vit. $\mathrm{B}_{2} 960$, vit. $B_{6} 960$, folic acid 640 , biotin 40 , vit. $B_{12} 6.4$, Se 64 , Co $64 ;{ }^{2}$ calculated values; EM - metabolic energy

last $5 \mathrm{~cm}$ of distal ileal part were collected as samples for further analysis. The obtained tissue fragments were washed twice with $0.9 \% \mathrm{NaCl}\left(4^{\circ} \mathrm{C}\right)$, and then with $20 \mathrm{mM} \mathrm{Krebs}-\mathrm{HEPES}$ buffer $\left(\mathrm{NaCl}, \mathrm{KCl}, \mathrm{CaCl}_{2}\right.$, $\mathrm{MgSO}_{4}, \mathrm{~K}_{2} \mathrm{HPO}_{4}, \mathrm{NaHCO}_{3}, \mathrm{pH} 7.4 ; 4^{\circ} \mathrm{C}$; Noxygene, Elzach, Germany). Next, the samples were frozen in liquid nitrogen and subsequently stored at $-80{ }^{\circ} \mathrm{C}$.

All experimental procedures were approved by the Local Commission of Ethics for the Care and Use of Laboratory Animals (No. 13/2012 of 23.05.2012, West Pomeranian University of Technology, Szczecin, Poland).

\section{Chemical composition of diets}

Diets were analyzed for dry matter, crude ash, crude protein, ether extract, crude fiber, and fructans according to AOAC International (2011) procedures. 


\section{Protein sample preparation}

After thawing the ileal fragments in the $0.9 \% \mathrm{NaCl}$, the intestinal mucosa was immediately scraped with the back of a surgery knife. A $100 \mathrm{mg}$ of a mucosal sample was homogenized with steel beads using Tissue Lyser (QIAGEN, Hilden, Germany) at a frequency of $22000 \mathrm{~Hz}$ for 5 min. Subsequently, samples were homogenized in lysis buffer $(7 \mathrm{M}$ urea, $2 \mathrm{M}$ thiourea, $4 \% \mathrm{w} / \mathrm{v}$ CHAPS, $1 \% \mathrm{w} / \mathrm{v}$ DTT, $2 \% \mathrm{v} / \mathrm{v}$ Biolyte, $1 \% \mathrm{v} / \mathrm{v}$ protease inhibitor cocktail, $0.1 \% \mathrm{v} / \mathrm{v}$ nuclease) at a frequency of $20000 \mathrm{~Hz}$ for $60 \mathrm{~min}$. Extant cell debris were sedimented by centrifugation $(20800 \mathrm{~g}$ for 3 min at $4{ }^{\circ} \mathrm{C}$ ), and next the supernatant containing solubilized mucosal proteins was collected.

\section{2-DE (two-dimensional electrophoresis)}

After the measurement of the total protein concentration using Bradford assay (Bio-Rad Protein Assay, Bio-Rad, Hercules, California, USA), linear 3-10, 24 cm ReadyStrip ${ }^{\mathrm{TM}}$ IPG Strips (Bio-Rad, Hercules, California, USA) were rehydrated with $650 \mu 1$ of sample containing $1000 \mu \mathrm{g}$ of total ileal mucosa protein (in two replicates). The isoelectrofocusing (IEF) was conducted in total of $90000 \mathrm{Vh}$ using a Protean $112^{\circledR}$ IEF Cell (Bio-Rad, Hercules, California, USA). The IPG strips were incubated for $15 \mathrm{~min}$ in basal equilibration buffer $(6 \mathrm{M}$ urea, $0.5 \mathrm{M}$ Tris/HCl, $\mathrm{pH} 6.8,2 \% \mathrm{w} / \mathrm{v}$ SDS, 30\% w/v glycerol) with $1 \%$ DTT followed by $20 \mathrm{~min}$ in the same basal buffer with $2.5 \%$ iodoacetamide. Second dimension run was performed at $40 \mathrm{~V}$ for $2.5 \mathrm{~h}$, and then at $100 \mathrm{~V}$ for $16 \mathrm{~h}$ at $10{ }^{\circ} \mathrm{C}$ with $12 \%$ polyacrylamide gels in Tris-glycine buffer $(25 \mathrm{mM}$ Tris- $\mathrm{HCl}$, $192 \mathrm{mM}$ glycine, $0.1 \%$ SDS) in a Protean Plus ${ }^{\mathrm{TM}}$ Dodeca Cell ${ }^{\mathrm{TM}}$ electrophoretic chamber (Bio-Rad, Hercules, California, USA). After 2-DE separation, proteins were visualized with colloidal Coomassie Brilliant Blue G-250.

\section{Image analysis}

Gels digitalization was performed using GS-800 ${ }^{\mathrm{TM}}$ Calibrated Densitometer (Bio-Rad, Hercules, California, USA). For analysis of protein spots expression pattern the PDQuest Advanced v. 8.0.1 (Bio-Rad, Hercules, California, USA) 2D-Gel analysis software was used. Experiment normalization was performed according to local regression model (LOESS). For the statistical analysis of the differences in relative abundance of protein spots Student's t-test was used as integrated in the PDQuest software. Significance of the differences was set at the level of $P \leq 0.05$. To analyze the intragroup variability coefficients of variation $(\mathrm{CV})$ for each group were calculat- ed. The experimental molecular masses of identified protein spots were determined using Precision Plus Protein $^{\mathrm{TM}}$ Kaleidoscope ${ }^{\mathrm{TM}}$ Standard for SDS-PAGE (Bio-Rad, Hercules, California, USA) as reference.

\section{Mass spectrometry}

For the identification of protein spots of statistically different expression MALDI-TOF (Matrix Associated Laser Desorption Ionization - Time of Flight) mass spectrometric identification was performed as previously described by Ozgo et al. (2015). For the identified gene products Gene Ontology analysis was performed based on the on-line tool STRING 11.0 (https://string-db.org/).

\section{Histological analysis}

Ileal tissue samples were taken, rinsed with physiological saline and fixed in Bouin's solution for 4 days. After dehydration in graded concentration of ethanol, tissues were cleared in xylene and embedded in paraffin blocks. The samples were then sliced into $5-\mu \mathrm{m}$ sections and stained with haematoxylin and eosin. For each sample two slides were prepared with a minimum of 4 sections. Villous height, crypt depth, mucosa thickness and myenteron thickness were determined using a Zeiss Axio Star Plus (Carl Zeiss, Göttingen, Germany) bright field microscope and Axio Vision LE Rel. 4.5 image analysis software (Carl Zeiss, Göttingen, Germany). At least 30 measurements of each parameter were performed per one sample and individual means were calculated. Data were analysed by one-way analysis of variance, followed by post hoc Tukey's HSD test using STATGRAPHICS ${ }^{\circledR}$ Centurion XVI ver. 16.1.03 statistical package (StatPoint Technologies, Inc., Warrenton, VA, USA).

\section{Results}

\section{Productive traits}

Feeding diets supplemented with IN or CR neither significantly affected feed intake and average daily gain nor final body weight of piglets (Lepczyński et al., 2017).

\section{Analysis of ileal proteome differences}

Bioinformatic analysis showed a similar number of protein spots on each analysed 2-DE gel representing ileal mucosa proteome (ranging from 457 to 524). Of these, 408 spots were included in the quantitative analysis aimed at comparing the expression pattern between control and experimental groups. The CV was estimated at the level of 49.20, 
45.99 and $51.70 \%$ for the C, IN and CR group, respectively.

Most of the significantly altered protein spots between gel images representing the $\mathrm{C}$ group and the IN or CR groups demonstrated similar trends in expression patterns; however, the differences were more pronounced in animals fed the CR diet.

Feeding the IN diet significantly altered the expression of 8 protein spots, 5 of which were downregulated and the remaining 3 were up-regulated in comparison to the $\mathrm{C}$ group. The $\mathrm{CR}$ diet was shown to induce significant expression changes of 35 protein spots, 18 of which were up-regulated and 17 were down-regulated in comparison to the $\mathrm{C}$ group. Detailed data concerning fold changes in protein expression and detailed parameters of protein spots identification are presented in Table 2. Additionally, example mass spectrum with original MASCOT search engine identification details are presented on Figure 1. Differentially expressed

A

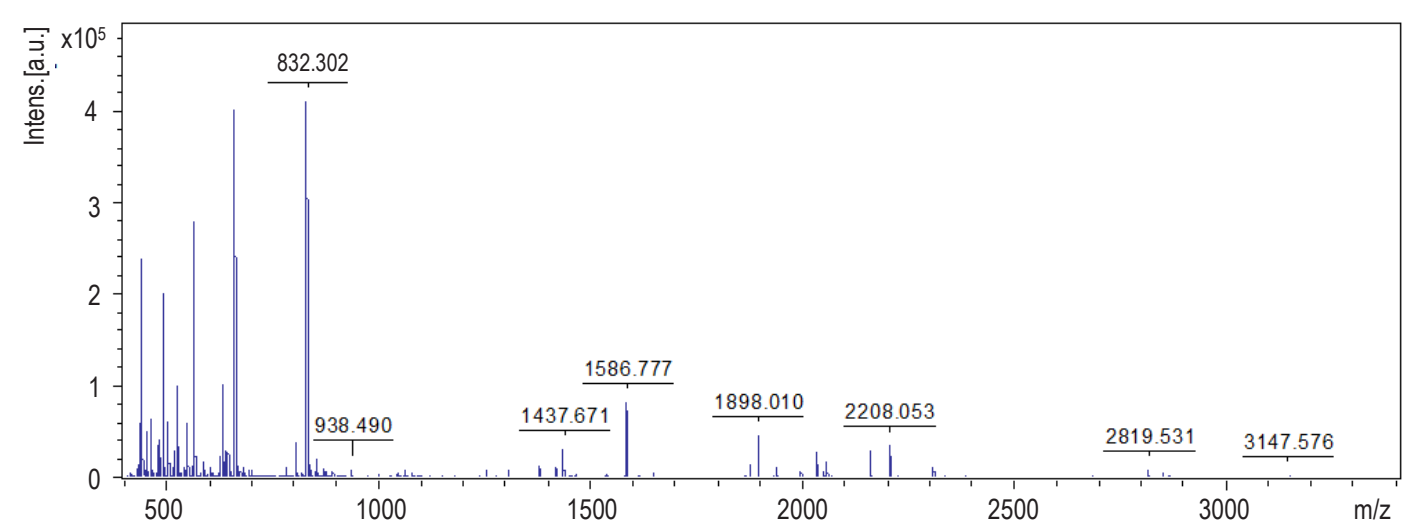

B Protein View: XP_003131510.1 keratin, type I cytoskeletal 20 [Sus scrofa]

$\begin{array}{ll}\text { Database: } & \text { NCBlprot } \\ \text { Score: } & 218 \\ \text { Expect: } & 6.8 \mathrm{e}-16 \\ \text { Monoisotopic mass }\left(\mathrm{M}_{\mathrm{H}}\right): & 49088 \\ \text { Calculated pl: } & 5.38 \\ \text { Taxonomy: } & \text { Sus scrofa }\end{array}$

\section{Search parameters}

\begin{tabular}{l} 
Enzyme: \\
Fixed modifications: \\
Variable modifications: \\
Mass values searched: \\
Mass values searched: \\
Start - End \\
$11-29$ \\
$30-52$ \\
$31-52$ \\
$58-77$ \\
$59-77$ \\
$96-109$ \\
$110-121$ \\
$122-134$ \\
$163-169$ \\
$173-193$ \\
$194-212$ \\
$213-222$ \\
$223-249$ \\
$223-249$ \\
$223-249$ \\
$250-262$ \\
$263-286$ \\
$298-313$ \\
$314-326$ \\
$334-349$ \\
$350-366$ \\
$367-377$ \\
$379-398$ \\
\hline 19
\end{tabular}

Trypsin: cuts $\mathrm{C}$-term side of $\mathrm{KR}$ unless next residue is $\mathrm{P}$.

Carbamidomethyl (C)

$\underline{\text { Oxidation (M) }}$

56

Observed $\quad \mathrm{Mr}(\exp$

$1940.9739 \quad 1939.9666 \quad 1939.9851$

$\begin{array}{lll}2162.0579 & 2161.0506 & 2161.0665\end{array}$

2033.9748 $2032.9676 \quad 2032.9715$

$\begin{array}{lll}2208.0529 & 2207.0456 & 2207.0607\end{array}$

$\begin{array}{lll}2051.9333 & 2050.9260 & 2050.9596\end{array}$

$1650.8433 \quad 1649.8360 \quad 1649.8624$

$1437.6706 \quad 1436.6633 \quad 1436.6684$

$\begin{array}{lll}1586.7771 & 1585.7699 & 1585.7849\end{array}$

$\begin{array}{rrr}938.4904 & 937.4832 & 937.4869\end{array}$

2312.2014 2311.1941 2311.2060

$2226.1698 \quad 2225.1625 \quad 2225.2154$

$\begin{array}{lll}1255.6106 & 1254.6034 & 1254.5840\end{array}$

$2852.4710 \quad 2851.4637 \quad 2851.3956$

$\begin{array}{lll}2868.4698 & 2867.4625 & 2867.3905\end{array}$

2884.4616 2883.4543 2883.3855

$1580.7385 \quad 1579.7312 \quad 1579.7664$

$2819.5313 \quad 2818.5240 \quad 2818.4600$

$\begin{array}{lll}1876.9348 & 1875.9275 & 1875.9578\end{array}$

$\begin{array}{llll}1468.7474 & 1467.7401 & 1467.7681\end{array}$

$\begin{array}{lll}1898.0099 & 1897.0026 & 1897.0269\end{array}$

$\begin{array}{lll}2058.9992 & 2057.9920 & 2058.0269\end{array}$

$\begin{array}{lll}1379.7199 & 1378.7126 & 1378.7204\end{array}$

Protein sequence coverage: $73 \%$

Matched peptides shown in bold red

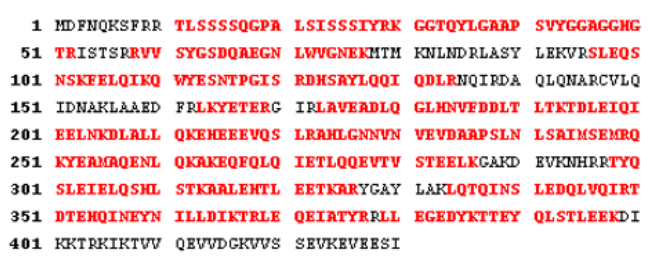

401 KKTRKIKTVV QBWVDGKVS SBVKBVBESI

Figure 1. Protein identification data on the example of keratin type I cytoskeletal 20

A - mass spectrum obtained using MALDI-TOF mass spectrometer (Microflex, Bruker, Bremen, Germany); B - protein identification parameters using the Mascot Search Engine: protein name, searched database, MASCOT score, expectation rate, number of matched peptides and amino acid sequence coverage; $\mathrm{C}$ - list of matched peptides; presented data are corresponding to those for spot number 6 in Table 2 
Table 2. Differentially expressed protein spots between the control $(\mathrm{C})$ and treatment groups (diets supplemented with $2 \%$ of chicory inulin (IN) or $4 \%$ of dried chicory root $(C R))$

\begin{tabular}{|c|c|c|c|c|c|c|c|c|c|c|}
\hline $\begin{array}{l}\text { Spot } \\
\text { No. }\end{array}$ & $\begin{array}{l}\text { t Accession No. } \\
\text { UniProt/NCBI }\end{array}$ & Protein name & $\begin{array}{l}\text { Gene } \\
\text { name }\end{array}$ & $\begin{array}{l}\text { Ratio } \\
\text { IN/C }\end{array}$ & $\begin{array}{l}\text { Ratio } \\
\mathrm{CR} / \mathrm{C}\end{array}$ & $\begin{array}{l}\text { Sequence } \\
\text { coverage (\%) / } \\
\text { MASCOT score }\end{array}$ & MP & SL & $\begin{array}{l}\text { Theo. pl / } \\
\text { MW (kDa) }\end{array}$ & $\begin{array}{l}\text { Exp. pl / } \\
\text { MW (kDa) }\end{array}$ \\
\hline \multicolumn{11}{|c|}{ Glycolysis/gluconeogenesis ${ }^{\mathrm{a}}$ and biosynthesis of amino acids ${ }^{\mathrm{b}}$} \\
\hline 1 & BAI48105 & triosephosphate isomerase $1^{\mathrm{ab}}$ & $T P l 1$ & 1.25 & 2.66 & $53 / 115$ & 9 & $\mathrm{CP}$ & $6.54 / 26.88$ & $6.9 / 27.8$ \\
\hline 2 & A0A287AJQ2 & phosphoglycerate mutase $1^{\mathrm{ab}}$ & PGAM1 & 1.16 & 2.72 & $46 / 94$ & 9 & $\mathrm{CP}$ & $6.67 / 28.90$ & $6.8 / 29.0$ \\
\hline 3 & XP_020949154 & $\begin{array}{l}\text { alcohol dehydrogenase [NADP+] } \\
\text { isoform } \mathrm{X}^{\mathrm{a}}\end{array}$ & $A K R 1 A 1$ & 0.97 & 2.33 & $32 / 96$ & 8 & $\mathrm{CP}$ & $6.51 / 36.84$ & $6.9 / 36.6$ \\
\hline 4 & P00355 & $\begin{array}{l}\text { glyceraldehyde-3-phosphate dehydro- } \\
\text { genase }^{\text {ab }}\end{array}$ & GAPDH & 0.83 & 0.63 & $25 / 61$ & 7 & $\mathrm{~N}, \mathrm{CP}, \mathrm{CS}$ & $8.51 / 36.04$ & $4.9 / 37.8$ \\
\hline 5 & XP_005672193 & $\begin{array}{l}\text { isocitrate dehydrogenase [NADP] } \\
\text { cytoplasmic isoform } \mathrm{X}^{\mathrm{b}}\end{array}$ & $I D H 1$ & 1.01 & 1.87 & $27 / 82$ & 8 & $\mathrm{CP}, \mathrm{PX}$ & $6.48 / 47.15$ & $6.6 / 46.1$ \\
\hline \multicolumn{11}{|c|}{ Cytoskeletal and related proteins } \\
\hline & XP_003131510 & keratin type I cytoskeletal 20 & KRT20 & 1.43 & 3.06 & $73 / 218$ & 23 & CS & $5.38 / 49.09$ & $5.5 / 51.5$ \\
\hline 7 & & & & 0.98 & 1.55 & $71 / 218$ & 25 & & & $5.4 / 54.2$ \\
\hline 8 & & & & 0.85 & 1.57 & $36 / 110$ & 10 & & & $5.5 / 54.4$ \\
\hline 9 & XP_001929280 & keratin type II cytoskeletal 8 & KRT8 & 1.46 & 1.74 & $54 / 246$ & 33 & CS & $5.70 / 54.39$ & $5.8 / 58.3$ \\
\hline 10 & P02543 & vimentin & VIM & 1.19 & 0.50 & $36 / 151$ & 17 & CS & $5.06 / 53.69$ & $4.6 / 51.3$ \\
\hline 11 & P67937 & tropomyosin alpha-4 chain & TPM4 & 0.91 & 0.78 & $40 / 98$ & 12 & CS & $4.67 / 28.62$ & $4.3 / 33.1$ \\
\hline 12 & NP._001123419.1 & tropomyosin beta chain & TPM2 & 1.09 & 0.59 & $22 / 89$ & 8 & CS & $4.62 / 33.38$ & $4.2 / 40.4$ \\
\hline 13 & Q6QAQ1 & actin cytoplasmic 1 & ACTB & 1.09 & 0.56 & $37 / 80$ & 11 & CS & $5.29 / 42.05$ & $5.3 / 38.8$ \\
\hline 14 & NP_001127815 & actin related protein 3 & ACTR3 & 0.96 & 3.03 & $31 / 109$ & 12 & CS & $5.61 / 47.85$ & $5.6 / 51.5$ \\
\hline 15 & XP_005659594 & annexin A2 & ANXA2 & 1.04 & 3.03 & $43 / 119$ & 12 & $\mathrm{CP}, \mathrm{N}, \mathrm{CM}$ & $6.92 / 38.84$ & $7.0 / 39.6$ \\
\hline 16 & Q99MZ8 & LIM and SH3 domain protein 1 & LASP1 & 1.20 & 2.17 & $40 / 95$ & 13 & CS & $6.61 / 30.35$ & $6.6 / 38.7$ \\
\hline 17 & P02554 & tubulin beta chain & TUBB & 0.93 & 0.65 & $52 / 197$ & 22 & CS & $4.78 / 50.29$ & $4.8 / 37.8$ \\
\hline 18 & & & & 0.67 & 0.43 & $31 / 86$ & 10 & & & $4.9 / 69.7$ \\
\hline 19 & & & & 0.73 & 0.09 & $29 / 77$ & 13 & & & $4.4 / 57.9$ \\
\hline 20 & XP_003358947 & T-complex protein 1 subunit theta & ССТ8 & 0.89 & 0.69 & $20 / 79$ & 8 & $\mathrm{CS}, \mathrm{CP}$ & $5.40 / 60.15$ & $5.3 / 67.6$ \\
\hline \multicolumn{11}{|c|}{ Protein synthesis and processing } \\
\hline 21 & P85834* & elongation factor TU, mitochondrial & TUFM & 0.9 & 1.28 & $15 / 62$ & 6 & MT & $7.23 / 49.89$ & $6.5 / 48.2$ \\
\hline 22 & XP_020939748 & elongation factor 2 isoform $\mathrm{X} 2$ & EEF2 & 1.17 & 1.53 & $38 / 133$ & 19 & $\mathrm{CP}, \mathrm{N}$ & $6.41 / 94.87$ & $6.8 / 78.9$ \\
\hline 23 & P68102* & $\begin{array}{l}\text { eukariotic translation initiation factor } 2 \\
\text { subunit } 1\end{array}$ & EIF2S1 & 0.57 & 0.24 & $39 / 77$ & 8 & $\mathrm{~N}, \mathrm{CP}$ & $5.02 / 36.37$ & $5.1 / 40.0$ \\
\hline 24 & XP_003133652 & elongation factor 1-beta & EEF1B2 & 0.79 & 0.69 & $29 / 91$ & 7 & $\mathrm{CP}$ & $4.51 / 24.96$ & $4.3 / 33.1$ \\
\hline 25 & Q3T165* & prohibitin $^{d}$ & PHB & 0.86 & 0.19 & $51 / 92$ & 8 & MT, EX & $5.57 / 29.84$ & $5.4 / 31.0$ \\
\hline 26 & NP_001182041 & $\begin{array}{l}\text { protein disulfide isomerase A3 } \\
\text { precursor }\end{array}$ & PDIA3 & 1.76 & 1.52 & $26 / 86$ & 10 & ER & $5.93 / 57.28$ & $5.9 / 61.8$ \\
\hline 27 & XP_020946788 & endoplasmin & HSP90B1 & 11.11 & 1.50 & $24 / 90$ & 13 & $\mathrm{ER}$ & $4.73 / 92.56$ & $4.6 / 111.4$ \\
\hline \multicolumn{11}{|c|}{ Cell proliferation and differentiation } \\
\hline 28 & XP_003359931 & proliferating cell nuclear antigen & PCNA & 0.58 & 0.75 & $54 / 139$ & 13 & $\mathrm{~N}$ & $4.57 / 29.10$ & $4.3 / 36.1$ \\
\hline 29 & P61288 & translationally-controled tumor protein & TCTP & 0.77 & 0.79 & $51 / 89$ & 9 & $\mathrm{CP}$ & $4.84 / 19.70$ & $4.7 / 25.6$ \\
\hline 30 & XP_020954120 & chloride intracellular channel protein 1 & CLIC1 & 0.6 & 0.52 & $45 / 91$ & 9 & $\mathrm{~N}, \mathrm{CM}$ & $5.17 / 27.30$ & $5.2 / 36.4$ \\
\hline \multicolumn{11}{|c|}{ Other proteins } \\
\hline 31 & CAA30943 & transferrin, partial & TF & 1.34 & 1.74 & $22 / 86$ & 12 & ES & $6.73 / 78.95$ & $6.6 / 83.4$ \\
\hline 32 & XP_003129266 & annexin A5 & ANXA5 & 1.06 & 0.53 & $66 / 220$ & 22 & $\mathrm{CP}, \mathrm{CM}$ & $4.94 / 36.17$ & $4.8 / 34.1$ \\
\hline 33 & CAA30970 & albumin & $A L B$ & 1.19 & 2.30 & $47 / 192$ & 20 & EX & $5.92 / 71.36$ & $6.0 / 72.3$ \\
\hline 34 & & & & 1.98 & 2.07 & $46 / 221$ & 21 & & & $5.9 / 71.0$ \\
\hline 35 & Q99028 & catechol o-methyltransferase & COMT & 1.02 & 0.52 & $50 / 61$ & 5 & $\mathrm{CP}, \mathrm{CM}$ & $6.10 / 20.89$ & $5.0 / 26.9$ \\
\hline
\end{tabular}

Spot number indicates the number labeling the spots in Figure 1; for each protein, accession number and protein name are shown as in Uniprot/NCBI database; the fold change (ratio IN/C; ratio $\mathrm{CR} / \mathrm{C}$ ), the predicted and estimated molecular weight (MW) and isoelectric point $(\mathrm{pl})$, the percentage of the sequence coverage, the Mascot score and the number of peptides matched per protein (MP) are also indicated; spots significantly differentially expressed at level $P \leq 0.05$ are bolded; proteins are grouped according to their function; subcellular localization (SL): CM - cell membrane, CP - cytoplasm, CS - cytoskeleton, ER - endoplasmic reticulum, ES - endosome, EX - extracellular, MT - mitochondrion, N - nucleus, PX - peroxisome; ${ }^{a}$ - proteins involved in glycolysis/gluconeogenesis; ${ }^{b}$ - proteins involved in biosynthesis of amino acids; ab - proteins involved in both glycolysis/gluconeogenesis and biosynthesis of amino acids; * - proteins identified as other organisms homologues; ${ }^{\dagger}$ - the protein spot which Maldi-TOF MS identification profile is presented on Figure 2 


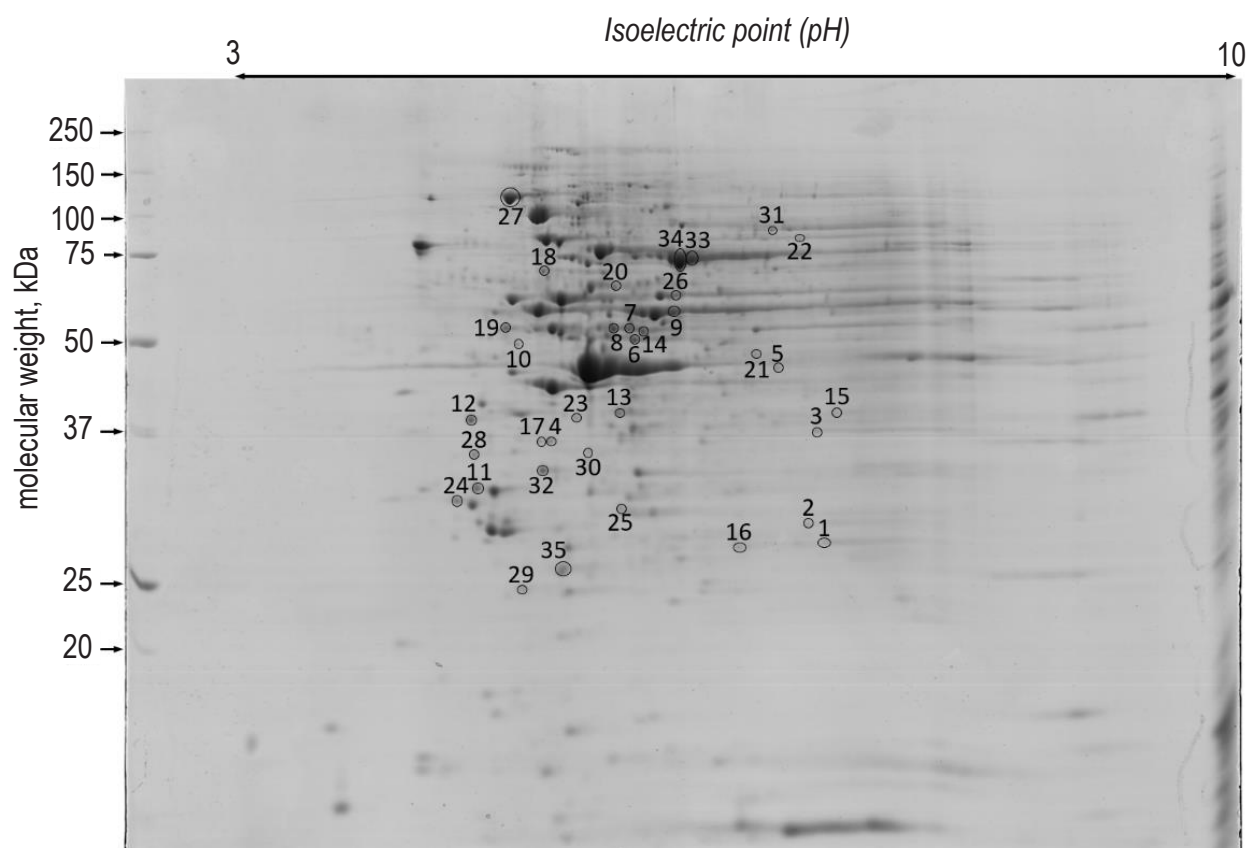

Figure 2. 2-DE map of differentially expressed protein spots found in the ileal mucosa of 50-day-old pigs fed both supplemented diets. Spot numbers correspond to those in Table 2

protein spots are marked on the representative gel image of the ileal mucosa protein profile (Figure 2).

Significantly altered proteins were categorized according to their biological function and known metabolic pathways based on the on-line Gene Ontology enrichment tool STRING 11.0 (https:// string-db.org/). On that basis the identified proteins were manually assigned to the following protein groups: glycolysis/gluconeogenesis and biosynthesis of amino acids, cytoskeletal and related proteins, protein synthesis and processing, cell proliferation and differentiation, and other proteins (Table 2). Significantly altered proteins were also grouped accordingly to their subcellular localisation (Table 2). The highest number of proteins in this group was classified as cytoplasmic and cytoskeletal proteins.

\section{Histological analysis}

Histological analysis including villous height, crypt depth, villus:crypt ratio, mucosa thickness and myenteron thickness did not show any statistical differences (Table 3).

Table 3. Morphological parameters of the ileum of pigs, $\mu \mathrm{m}$

\begin{tabular}{llllll}
\hline Group & $\begin{array}{l}\text { Villous } \\
\text { height } \\
(\mathrm{VH}), \mu \mathrm{m}\end{array}$ & $\begin{array}{l}\text { Crypt depth } \\
(\mathrm{CD}), \mu \mathrm{m}\end{array}$ & $\mathrm{VH}: \mathrm{CD}$ & $\begin{array}{l}\text { Mucosa } \\
\text { thickness, } \\
\mu \mathrm{m}\end{array}$ & $\begin{array}{l}\text { Myenteron } \\
\text { thickness, } \\
\mu \mathrm{m}\end{array}$ \\
\hline Control & 341 & 246 & 1.42 & 586 & 619 \\
Inulin (2\%) & 324 & 235 & 1.41 & 565 & 652 \\
$\begin{array}{l}\text { Dried chicory } \\
\text { root (4\%) }\end{array}$ & 339 & 227 & 1.52 & 541 & 578 \\
$\quad$ SEM & 7.3 & 4.4 & 0.047 & 10.0 & 31.2 \\
\multicolumn{1}{c}{ P-value } & 0.6332 & 0.1677 & 0.6055 & 0.1799 & 0.6499 \\
\hline
\end{tabular}

\section{Discussion}

In the present study, a significant influence of native inulin and inulin rich-chicory root was observed on the expression level of several proteins involved in glycolysis/gluconeogenesis and metabolism of amino acids. The influence of ITFs on the protein and transcriptome expression pattern of the small intestine cells has not been analysed yet, but several studies evidenced the effect of inulin and SCFAs (butyrate, propionate and acetate) on Caco-2 cells (Lamers et al., 2003; Chang et al., 2008) that may partially reflect the metabolic properties of ileal enterocytes. Lamers et al. (2003) noticed that inulin and SCFAs cause changes in the level of metabolites associated with glucose metabolism and glutamate synthesis in this cell line. An increase in glucose, glutamate and alanine concentrations was observed after incubating the cells in a medium containing native inulin. On the other hand, an increase in the concentration of metabolites related to tricarboxylic acid cycle activity (i.e. alanine, succinate, lactate and 2-oxoglutarate), proline and its precursors (nicotinamide, nicotinate) was observed as a result of incubation of Caco-2 cells with inulin fermentation products, which could indicate increased glycolytic activity of these cells. The effect of butyrate on the expression profile of glycolytic enzymes (i.e. PGAM1) at the transcript level in Caco-2 cells was also reported by Chang et al. (2008). Additionally, Wang et al. (2012) demonstrated an increased expression of isocitrate dehydrogenase (IDH) 
protein isoforms in the jejunum of weanling piglets as a result of dietary supplementation with the $L a c$ tobacillus fermentum 15007 probiotic strain. Thus, it can be concluded that changes in the expression of glycolytic enzymes: triose phosphate isomerase (TPI1), phosphoglycerate mutase 1 (PGAM1), alcohol dehydrogenase [NADP+] (AKR1A1), glyceraldehyde-3-phosphate dehydrogenase (GAPDH) and isocitrate dehydrogenase 1 (IDH1), in our study may result from an increased number of probiotic bacteria colonizing the small intestine and/or subsequent inulin fermentation in this segment of the small intestine. This hypothesis is strengthened by the fact that ITF fermentation in the small intestine of growing pigs was confirmed by Yasuda et al. (2009). Our findings also showed that ITFs affected cell proliferation and differentiation by down-regulating proliferating cell nuclear antigen (PCNA) and translationally-controled tumor protein (TCTP) in animals fed diets supplemented with inulin and chicory root. PCNA expression is strictly corelated with proliferative cells at the final stage of the G1 phase and the initial stage of the S phase typically occurs in intestinal crypt cells (Paunesku et al., 2001). It has been also confirmed that the administration of prebiotics and probiotics in pigs cause a decrease in the number of PCNA-positive crypt cells in the ileal mucosa, that exhibited progression towards reduced epithelial proliferation (Rekiel et al., 2010). TCTP is a protein involved inter alia in cell growth, cell cycle progression and stress resistance as a molecular chaperone (Bommer, 2012). TCTP shows strong polarisation along the crypt-villus axis. Its expression is relatively high in the crypt and low in the villi (Sheverdin et al., 2013). In our study we have not observed significantly important differences in morphometric measurements of ileal mucosa, but the fact that animals fed diet supplemented with dried chicory root had the relatively shorter crypt depth, the lowest expression of PCNA and TCTP. Taken all together it may evidence the relatively highest maturity of intestinal mucosa in this animal group. The crypt depth is a marker of intestinal mucosa maturity. Increased crypt cell proliferation counteracts the rate of reduction in villous height and eventually equalled the rate of cell loss from the villi in postweaning intestine rearrangement (Hampson, 1986; Masri et al., 2015). It may suggest that decreased crypt depth in the animals fed both experimental diets may be the effect of less intense rearrangement of villi in the postweaning period. Additionally, Masri et al. (2015) stated that morphometric indices (villous height, crypt depth, villous:crypt ratio) should not be considered individually, but should be treated as an entity, forming an overall picture of mucosa status. In our opinion, this statement should replenish molecular markers of functional mucosa maturity e.g., protein expression pattern.

In our study, significant differences in the expression of ileal cytoskeletal proteins were observed in animals fed diet supplemented with chicory root. These changes were observed for both intermediate filament and thin filament constituents as well as microfilaments and cytoskeleton-associated proteins. It clearly shows that inulin affects mucosal maintenance and integrity. It has been confirmed that ITFs and SCFAs, mainly butyrate, appear to play an important role in regulating epithelial barrier integrity by regulating the expression and distribution of tight junction proteins in vitro $(\mathrm{Wu}$ et al., 2017) and in vivo in the pig ileum (Diao et al., 2017). In our study, we did not observe differences in the expression of main tight junction-forming proteins (e.g., zona ocludens-1, claudins, ocludins), but we found a 3-fold up-regulation of annexin A2 (ANXA2) in the CR group. ANXA2 is proposed as a member of tight junction-related proteins responsible for its proper function and assembly (Lee et al., 2004). ANXA2 was also up-regulated in the ileum of broilers treated with Enterococcus fecium probiotic (Luo et al., 2013). Moreover, ANXA2 may protect against oxidative stress. According to Madureira et al. (2011), ANXA2 was responsible for protecting lipids, proteins and nucleic acids from oxidative damage by participating in $\mathrm{H}_{2} \mathrm{O}_{2}$ reduction. The proposed mechanism included oxidation of the ANXA2 Cys- 8 residue by $\mathrm{H}_{2} \mathrm{O}_{2}$ and its subsequent reduction by the thioredoxin system. It is known that ITFs (Pasqualetti et al., 2014) and their metabolites (Hamer et al., 2010) exhibit antioxidant effects in intestinal epithelial cells. Recently, such an effect of ITFs has also been found in the liver of piglets (Lepczyński et al., 2017). The antioxidant activity of inulin can be enhanced by polyphenol compounds present in chicory root (Montefusco et al., 2015).

In our study, we also observed a marked upregulation of actin-related protein 3 (ACTR3) in the mucosa of animals fed diet supplemented with chicory root. This protein is crucial for the formation and stabilisation of intestinal epithelium adherence junctions (Bernadskaya et al., 2011). Additionally, Johnson-Henry et al. (2014) observed an intense rearrangement of actin cytoskeleton in the Caco2BBe subclones epithelial cell layer after its co-incubation with inulin and fructooligosaccharides. It can be assumed that up-regulation of these proteins 
may reflect the improved integrity of the intestinal mucosa. Inulin itself and its fermentation products may influence the development of intestinal mucosa (Lu et al., 2008; Awad et al., 2013). In our study, we observed an increased expression of keratin type I cytoskeletal 20 (KRT20) and keratin type II cytoskeletal 8 (KRT8) in animals fed both supplemented diets in comparison to control animals; these proteins are the most abundant cytokeratins in ileal epithelial cells (Zhou et al., 2003). It has been recently described that incubation of Caco-2 cells in the medium with $\beta$-hydroxybutyrate can stimulate its differentiation into absorptive enterocyte phenotype exhibiting strong expression of KRT20, which is a known marker of absorptive epithelial cells (Wang et al., 2017). Higher expression of KRT20 in the absorptive part of the intestine was also confirmed in mouse (Chang et al., 2008). Moreover, larger ileal villi and higher KRT20 expression were observed in broiler chickens fed diet supplemented with probiotic Enterococcus faecium (Luo et al., 2013). According to these findings, the increased KRT20 expression, accompanied by ANXA2 up-regulation, may facilitate rapid turnover of cellular proteins. Changes in KRT8 expression may be the effect of SCFA production by inulin-fermenting bacteria, as KRT8 may be involved in butyrate metabolism in colonocytes (Helenius et al., 2015). Additionally, its increased abundance was observed in mucosal cells of probiotic-supplemented piglets (Wang et al., 2012).

Transferrin attracted our great attention from the group of other differentially expressed proteins. This protein is not expressed in the ileum (Idzerda et al., 1986), but it can be transferred to the enterocyte via the receptor-mediated endocytosis pathway (Morgan and Oates, 2002). Transferrin receptor (TfR) expression and transferrin abundance in the small intestine mucosa strictly reflect iron status and are inversely correlated with iron level in the enterocyte under physiological conditions (Kolachala et al., 2007). Tako et al. (2008) described the impact of ITFs on duodenal and caecal expression of proteins involved in iron absorption and metabolism at both transcript and protein levels in growing pigs. These authors observed increased TfR expression in the intestine and higher blood haemoglobin concentration in pigs fed for 6 weeks diet supplemented with ITFs in comparison to animals fed standard diet. Furthermore, the up-regulation of genes coding for iron enzymes, receptors and binding protein in the duodenum suggests that inulin itself may directly affect gene expression in enterocytes
(Tako et al., 2008). Additionally, in our previous paper, the analysis performed on the same group of animals showed that pigs fed a diet supplemented with dried chicory root had significantly higher blood plasma iron concentration $(30.5 \mu \mathrm{mol} / \mathrm{l})$ in comparison to animals fed a control diet $(15.6 \mu \mathrm{mol} / \mathrm{l})$ and a diet supplemented with $2 \%$ of native chicory inulin $(19.8 \mu \mathrm{mol} / \mathrm{l})$ (Lepczyński et al., 2016). Thus, the increased ileal accumulation of transferrin, found in the present study, may be caused by direct effect of chicory root bioactive compounds leading to the improvement of iron status in growing pigs.

\section{Conclusions}

Changes in the expression of proteins associated with energetic metabolism, cell proliferation and cytoskeletal proteins may suggest an impact of dried inulin type fructans-rich chicory root on the functional maturation of the ileal mucosa. Additionally, changes in transferrin abundance suggest the significance of chicory root and native inulin supplementation for iron absorption in the small intestine of growing pigs. Nevertheless, further studies are necessary to better understand the mechanism underlying inulin effect on the ileum of growing pigs.

\section{Acknowledgment}

The authors gratefully acknowledge the financial assistance of National Centre of Science, Poland (Project No. 2012/05/D/NZ9/01604).

\section{References}

AOAC International, 2011. Official Methods of Analysis of AOAC International. Current Through Revision 4. $18^{\text {th }}$ Edition. Gaithersburg, MD (USA)

Awad W.A., Ghareeb K., Paßlack N., Zentek J., 2013. Dietary inulin alters the intestinal absorptive and barrier function of piglet intestine after weaning. Res. Vet. Sci. 95, 249-254, https:// doi.org/10.1016/j.rvsc.2013.02.009

Barszcz M., Taciak M., Skomiał J., 2018. Influence of different inclusion levels and chain length of inulin on microbial ecology and the state of mucosal protective barrier in the large intestine of young pigs. Anim. Prod. Sci. 58, 1109-1118, https://doi. org/10.1071/AN16014

Bernadskaya Y.Y., Patel F.B., Hsu H.-T., Soto M.C., 2011. Arp2/3 promotes junction formation and maintenance in the Caenorhabditis elegans intestine by regulating membrane association of apical proteins. Mol. Biol. Cell 22, 2886-2899, https://doi.org/10.1091/mbc.e10-10-0862

Bommer U.-A., 2012. Cellular function and regulation of the translationally controlled tumour protein TCTP. Open Allergy J. 5, 19-32, http://doi.org/10.2174/1874838401205010019 
Chang J., Chance M.R., Nicholas C. et al., 2008. Proteomic changes during intestinal cell maturation in vivo. J. Proteomics 71, 530546, https://doi.org/10.1016/j.jprot.2008.08.003

Diao H., Jiao A.R., Yu B. et al., 2017. Stimulation of intestinal growth with distal ileal infusion of short-chain fatty acid: a reevaluation in a pig model. RSC Adv. 7, 30792-30806, https://doi. org/10.1039/C7RA03730A

Gałazka I., 2002. The composition of chicory flour of selected chicory cultivars Polanowicka and Fredonia in relation to root sizes and the date of harvest. Zywn.-Nauk Technol. Jakosc 3(32), Suppl., $37-45$

Gibson G.R., Hutkins R., Sanders M.E. et al., 2017. Expert consensus document: The International Scientific Association for Probiotics and Prebiotics (ISAPP) consensus statement on the definition and scope of prebiotics. Nat. Rev. Gastroenterol. Hepatol. 14, 491-502, https://doi.org/10.1038/nrgastro.2017.75

Hamer H.M., Jonkers D.M., Vanhoutvin S.A., Troost F.J., Rijkers G., de Bruine A., Bast A., Venema K., Brummer R.J., 2010. Effect of butyrate enemas on inflammation and antioxidant status in the colonic mucosa of patients with ulcerative colitis in remission. Clin. Nutr. 29, 738-744, https://doi.org/10.1016/j. clnu.2010.04.002.

Hampson D.J., 1986. Alterations in piglet small intestinal structure at weaning. Res. Vet. Sci. 40, 32-40, https://doi.org/10.1016/ S0034-5288(18)30482-X

Helenius T.O., Misiorek J.O., Nyström J. et al., 2015. Keratin 8 absence down-regulates colonocyte HMGCS2 and modulates colonic ketogenesis and energy metabolism. Mol. Biol. Cell 26, 22982310, https://doi.org/10.1091/mbc.E14-02-0736

Idzerda R.L., Huebers H., Finch C.A., McKnight G.S., 1986. Rat transferrin gene expression: tissue-specific regulation by iron deficiency. Proc. Natt. Acad. Sci. U. S. A. 83, 3723-3727, https://doi.org/10.1073/pnas.83.11.3723

Johnson-Henry K.C., Pinnell L.J., Waskow A.M., Irrazabal T., Martin A., Hausner M., Sherman P.M., 2014. Short-chain fructooligosaccharide and inulin modulate inflammatory responses and microbial communities in Caco2-bbe cells and in a mouse model of intestinal injury. J. Nutr. 144, 1725-1733, https://doi. org/10.3945/jn.114.195081

Kolachala V.L., Sesikeran B., and Nair K.M., 2007. Evidence for a sequential transfer of iron amongst ferritin, transferrin and transferrin receptor during duodenal absorption of iron in rat and human. World J. Gastroenterol. 13, 1042-1052, https://doi. org/10.3748/wjg.v13.i7.1042

Lamers R.-J.A.N., Wessels E.C.H.H., van de Sandt J.J.M., Venema K., Schaafsma G., van der Greef J., van Nesselrooij J.H.J., 2003. A pilot study to investigate effects of inulin on Caco-2 cells through in vitro metabolic fingerprinting. J. Nutr. 133, 30803084, https://doi.org/10.1093/jn/133.10.3080

Lee D.B., Jamgotchian N., Allen S.G., Kan F.W.K., Hale I.L., 2004. Annexin A2 heterotetramer: role in tight junction assembly. Am. J. Physiol. Renal Physiol. 287, F481-F491, https://doi. org/10.1152/ajprenal.00175.2003

Lepczyński A., Herosimczyk A., Barszcz M., Ożgo M., Taciak M., Skomiał J., 2016. Inulin-type fructans trigger changes in iron concentration and activity of bone metabolism biomarkers in blood plasma of growing pigs. J. Anim. Feed Sci. 25, 343-347, https://doi.org/10.22358/jafs/67471/2016

Lepczyński A., Herosimczyk A., Ożgo M., Marynowska M., Pawlikowska M., Barszcz M., Taciak M., Skomiał J., 2017. Dietary chicory root and chicory inulin trigger changes in energetic metabolism, stress prevention and cytoskeletal proteins in the liver of growing pigs - a proteomic study. J. Anim. Physiol. Anim. Nutr. 101, e225-e236, https://doi. org/10.1111/jpn.12595
Lu J.J., Zou X.T., Wang Y.M., 2008. Effects of sodium butyrate on the growth performance, intestinal microflora and morphology of weanling pigs. J. Anim. Feed Sci. 17, 568-578, https://doi. org/10.22358/jafs/66685/2008

Luo J., Zheng A., Meng K., Chang W., Bai Y., Li K., Cai H., Liu G., Yao B., 2013. Proteome changes in the intestinal mucosa of broiler (Gallus gallus) activated by probiotic Enterococcus faecium. J. Proteomics 91, 226-241, https://doi.org/10.1016/j. jprot.2013.07.017

Madureira P.A., Hill R., Miller V.A., Giacomantonio C., Lee P.W.K., Waisman D.M., 2011. Annexin A2 is a novel cellular redox regulatory protein involved in tumorigenesis. Oncotarget 2 , 1075-1093, https://doi.org/10.18632/oncotarget.375

Masri Al S., Hünigen H., Al Aiyan A., Rieger J., Zentek J., 2015. Influence of age at weaning and feeding regimes on the postnatal morpholog y of the porcine small intestine. J. Swine Health Prod. 23, 186-203

Montefusco A., Semitaio G., Marrese P.P., Iurlaro A., De Caroli M., Piro G., Dalessandro G., Lenucci M.S., 2015. Antioxidants in varieties of chicory (Cichorium intybus L.) and wild poppy (Papaver rhoeas L.) of Southern Italy. J. Chem. 2015, 923142, http://doi.org/10.1155/2015/923142

Morgan E.H., Oates P.S., 2002. Mechanisms and regulation of intestinal iron absorption. Blood Cells Mol. Dis. 29, 384-399, https://doi.org/10.1006/bcmd.2002.0578

Ozgo M., Lepczynski A., Herosimczyk A., 2015. Two-dimensional gelbased serum protein profile of growing piglets. Turk. J. Biol. 39, 320-327, https://doi.org/10.3906/biy-1408-45

Pasqualetti V., Altomare A., Guarino MP. Et al., 2014. Antioxidant activity of inulin and its role in the prevention of human colonic muscle cell impairment induced by lipopolysaccharide mucosal exposure. PLoS One. 9, e98031. https://doi. org/10.1371/journal.pone.0098031

Paunesku T., Mittal S., Proctić M., Oryhon J., Korolev S.V., JoachimiakA., Woloschak G.E., 2001. Proliferating cell nuclear antigen (PCNA): ringmaster of the genome. Int. J. Radiat. Biol. 77, 1007-1021, https://doi.org/10.1080/09553000110069335

Rekiel A., Bielecki W., Więcek J., Kulisiewicz J., 2010. Histological changes in the small intestinal epithelium in fattening pigs fed selected feed additives. Acta Vet. Brno 79, 67-71, https://doi. org/10.2754/avb201079010067

Sheverdin V., Jung J., Lee K., 2013. Immunohistochemical localization of translationally controlled tumor protein in the mouse digestive system. J. Anat. 223, 278-288, https://doi. org/10.1111/joa.12077

Tako E., Glahn R.P., Welch R.M., Lei X., Yasuda K., Miller D.D., 2008. Dietary inulin affects the expression of intestinal enterocyte iron transporters, receptors and storage protein and alters the microbiota in the pig intestine. Br. J. Nutr. 99, 472-480, https://doi.org/10.1017/S0007114507825128

Wang Q., Zhou Y., Rychahou P., Fan T.W.-M., Lane A.N., Weiss H.L., Evers B.M., 2017. Ketogenesis contributes to intestinal cell differentiation. Cell Death Differ. 24, 458-468, https://doi. org/10.1038/cdd.2016.142

Wang X., Yang F., Liu C., Zhou H., Wu G., Qiao S., Li D., Wang J., 2012. Dietary supplementation with the probiotic Lactobacillus fermentum 15007 and the antibiotic aureomycin differentially affects the small intestinal proteomes of weanling piglets. J. Nutr. 142, 7-13, https://doi.org/10.3945/jn.111.147074

Wu R.Y., Abdullah M., Määttänen P., Pilar A.V., Scruten E., JohnsonHenry K.C., Napper S., O'Brien C., Jones N.L., Sherman P.M., 2017. Protein kinase $C \delta$ signaling is required for dietary prebiotic-induced strengthening of intestinal epithelial barrier function. Sci. Rep. 7, 40820, https://doi.org/10.1038/ srep40820 
Yasuda K., Dawson H.D., Wasmuth E.V., Roneker C.A., Chen C., Urban J.F., Welch R.M., Miller D.D., Lei X.G., 2009. Supplemental dietary inulin influences expression of iron and inflammation related genes in young pigs. J. Nutr. 139, 2018-2023, https://doi.org/10.3945/jn.109.110528
Zhou Q., Toivola D.M., Feng N., Greenberg H.B., Franke W.W., Omary M.B., 2003. Keratin 20 helps maintain intermediate filament organization in intestinal epithelia. Mol. Biol. Cell 14, 2959-2971, https://doi.org/10.1091/mbc.E0302-0059 